\title{
IPTEKS SISTEM INFORMASI AKUNTANSI DALAM AKTIVITAS PENCAIRAN DANA PADA KANTOR WILAYAH KEMENTERIAN AGAMA PROVINSI SULAWESI UTARA
}

\author{
Abdul Wahid Supriatna Mile ${ }^{1}$, Sonny Pangerapan ${ }^{2}$ \\ ${ }^{1,2}$ Jurusan Akuntansi, Fakultas Ekonomi dan Bisnis Universitas Sam Ratulangi, Jl. Kampus Unsrat, Manado, \\ 95115, Indonesia. \\ E-mail : ryanmile.rm@gmail.com
}

\begin{abstract}
The system is a series of two or more interconnected components, which is interact to achieve a goal. This study aims to determine the role of accounting information systems in disbursing funds in the Regional Office of the Ministry of Religion of North Sulawesi Province. The method used in this writing is qualitative descriptive. The results of this study can be seen that the importance of accounting information systems for the Regional Office of the Ministry of Religion of North Sulawesi Province. With the existence of a good Accounting Information System, companies can carry out operations and information processes more effectively and efficiently because of the controls that control these processes so that the results achieved can be in accordance with the objectives of the agency.

Keyword: Accounting information system, procedure for disbursing funds
\end{abstract}

\section{PENDAHULUAN}

Sistem yang merupakan rangkaian dari komponen-komponen yang mempunyai korelasi penting, yang bisa melakukan interaksi untuk mencapai suatu tujuan. Informasi yang merupakan kumpulan data yang bisa diolah sehingga bisa dijadikan dasar dalam pengambilan keputusan. Karakteristik informasi yang tepat harus memenuhi beberapa ketentuan, diantaranya yaitu berkaitan dengan relevansi , tepat waktu, tepat sasaran dan lengkap. Sedangkan Akuntansi menurut Arnold merupakan sistem yang menyediakan informasi untuk semua orang yang bisa digunakan dalam pengambilan keputusan serta sebagai alat untuk mengendalikan penerapan keputusan tersebut.

Sistem Informasi Akuntansi yang paling efektif sangat berperan penting bagi keberhasilan jangka panjang suatu organisasi. Setiap organisasi juga perlu menelusuri seberapa besar pengaruh berbagai aktivitas dari pekerja yang berada di bawah pengawasannya. Informasi tentang para pelaku yang terlibat langsung di dalam aktivitas tersebut berperan penting untuk dapat bertanggung jawab dari tindakan yang diambil.

\section{TINJAUAN PUSTAKA}

Sistem yang merupakan suatu kesatuan dari komponen - komponen atau elemen yang dihubungkan bersama untuk memudahkan aliran daripada informasi.

Informasi, menurut Jogiyanto HM merupakan hasil dari olah data yang sudah terbentuk menjadi sesuatu yang berguna untuk penerimanya dengan menggambarkan kejadian nyata yang bermanfaat dalam pengambilan keputusan.

Akuntansi. Menurut American Accounting Association adalah bagian dari proses identifikasi, pengukuran dan pelaporan informasi yang berkaitan dengan hal ekonomi yang memungkinkan adanya penilaian keputusan bagi para pengguna informasi tersebut.

Sistem Informasi Akuntansi, menurut Barry E. Cushing sistem informasi akuntansi merupakan sebagian perangkat manusia dan modal dalam suatu organisasi, yang memiliki 
kewajiban untuk menyajikan informasi keuangan dan juga informasi yang diperoleh dari pengumpulan dan memproses data.

Komponen dalam sistem informasi akuntansi. Di dalam sistem informasi akuntansi terdapat 6 komponen, yaitu:

1. Blok masukan. Blok masukan merupakan blok yang memasukkan data ke dalam sistem akuntansi beserta metode yang nanti akan digunakan untuk memasukkan data tersebut ke dalam suatu sistem. Di dalam blok masukan terdapat beberapa aktivitas didalamnya antara lain transaksi, pernyataan, permintaan, perintah dan pesan.

2. Blok model. Blok Model terdiri dari model logika - matematik yang berfungsi untuk mengolah data yang dimasukkan dan disimpan dengan berbagai cara untuk dapat memproduksi hasil dan dapat menggabungkan suatu data secara optimal menjadi suatu laporan yang ringkas.

3. Blok Keluaran. Blok Keluaran merupakan produk dari sistem informasi yang hasilnya berupa informasi dan dokumen yang dibutuhkan untuk semua tingkatan manajemen dan semua pengguna informasi, entah pemakai informasi internal maupun eksternal.

4. Blok Teknologi. Blok teknologi adalah suatu alat penunjang di dalam sistem ini, dimana teknologi dapat menangkap, menjalankan, menyimpan, mengakses, dan menghasilkan data keluaran serta mengendalikan seluruh sistem.

5. Blok Basis Data. Blok basis data dipergunakan untuk menyimpan data yang untuk pelayanan kebutuhan pengguna informasi. Basis data dibedakan mejadi 2 yaitu secara fisik dan secara logis. Dimana basis data secara fisik melalui media penyimpanan data berupa disker, pita magnetik kaset, dan lainnya. Sedangkan basis data secara logis yaitu bagaimana struktur penyimpanan data bisa menjamin keakuratan, dann relevansi penyajian data atau informasi untuk memenuhi kebutuh dari setiap pemakai informasi dalam pengambilan keputusan.

6. Blok Pengendalian. Blok pengendalian merupakan keseluruhan dari sistem informasi yang terkait harus bisa mendapatkan perlindungan dari setiap bencana berupa kebakaran, kecuarangan, penggelapan, sabotase, dan kecurangan buruk lainnya.

\section{METODE DAN TEKNIK PENERAPAN IPTEKS}

3.1. Metode Penerapan Ipteks

Metode ipteks yang diterapkan adalah mengimplementasikan sistem informasi akuntansi sesuai dengan aturan yang berlaku.

\subsection{Teknik Penerapan Ipteks}

Melalui Penelitian yang dilakukan, diterapkan teknik ipteks yaitu melakukan observasi secara langsung terhadap sistem informasi akuntansi yang berlaku pada aktivitas pencairan dana pada objek yang dimaksud, sesuai dengan PerMen Agama Nomor 45 tahun 2014 tentang Pejabat Perbendaharaan Negara pada Kementerian Agama.

\section{PEMBAHASAN}

\subsection{Gambaran Objek Penerapan Ipteks}

Aktivitas pencairan dana yang dilakukan Kantor Wilayah Kementerian Agama Provinsi Sulut adalah suatu aktivitas yang secara langsung berhubungan dengan KPPN (Kantor Pelayanan Perbendaharaan Negara). KPPN merupakan sebuah instansi vertikal Pemerintah Pusat yang bertanggung jawab langsung kepada Kepala Kantor Wilayah Direktorat Jenderal Perbendaharaan, Ditjen Perbendaharaan-Kementerian Keuangan. Pencairan dana yang dilakukan merupakan aktivitas pada akun belanja.

\subsection{Pembahasan}

Jenis-Jenis Pencairan dana pada Kanwil Kemenag Provinsi Sulut : 
1. Akun Belanja Pegawai (51). Belanja pegawai merupakan akun yang termasuk dalam belanja negara dimana didalamnya memuat akun-akun yang berhubungan dengan kesejahteraan pegawai seperti akun belanja gaji dan tunjangan pegawai, akun belanja honor/lembur/tunjangan khusus pegawai, serta tunjangan pensiun pegawai.

2. Akun Belanja Barang dan Jasa (52). Akun belanja ini merupakan akun yang termasuk dalam belanja negara dimana didalamnya terdapat akun-akun yang berhubungan dengan kebutuhan kantor seperti akun belanja barang operasional / non operasional, akun belanja jasa, akun belanja pemeliharaan, akun belanja perjalanan dinas, dan akun belanja barang yang diserahkan kepada masyarakat.

3. Akun Belanja Modal (53). Akun belanja ini juga termasuk dalam belanja negara yang didalamnya terdapat akun-akun yang berhubungan dengan pengeluaran untuk pengadaan keperluan kantor seperti akun belanja modal peralatan dan mesin, akun belanja modal gedung dan bangunan dan akun belanja modal lainnya.

4. Akun Belanja Bantuan Sosial (57). Sama seperti akun-akun lainnya, akun belanja ini pun merupakan akun yang termasuk dalam belanja negara. Akun belanja bantuan sosial ini memuat akun-akun belanja yang bertujuan untuk membantu masyarakat pada umumnya. Dalam akun belanja ini terdapat akun belanja bantuan utnuk rehabilitasi sosial, akun belanja bantuan untuk jaminan sosial, pemberdayaan sosial hingga penanggulangan bencana

Prosedur Pencairan dana pada Kanwil Kemenag Provinsi Sulut. Secara umum, prosedur pencairan dana pada Kantor Wilayah Kementerian Agama Provinsi Sulut adalah dengan mengajukan Surat Permintaan Pembayaran serta dokumen-dokumen keterangan lainnya dari Sub bagian yang membutuhkan kepada Sub bagian perencanaan dan keuangan. Kemudian, dokumen tersebut akan diperiksa oleh verifikator pada bagian perencanaan dan keuangan jika sudah sesuai dengan yang dibutuhkan. Verifikator akan memeriksa dokumen sesuai jenis belanja yang dibutuhkan. Setelah itu, baru akan diproses dengan mengeluarkan Surat Permintaan Membayar sesuai kode belanja yang diajukan. Selanjutnya, akan dibawa ke KPPN untuk diperiksa kembali kesesuaian kode dan kebutuhan. Jika sudah sesuai, baru akan dicairkan dana yang dibutuhkan. Dokumen-dokumen yang harus diperiksa verifikator adalah berkas yang dibutuhkan sesuai jenis belanja. Berikut adalah checklist berkas yang harus diperiksa verifikator sesuai jenis belanjanya.

1. Belanja Pegawai. Checklist Pengeluaran yang harus diperiksa pada umumnya adalah:

a. Surat Permintaan Pembayaran lembar A, dimana tertulis total nominal yang harus dicairkan

b. Daftar Gaji, Rekap Daftar Gaji \& Halaman Luar Daftar Gaji yang ditandatangani oleh PPABP (Petugas Pengelolaan Administrasi Belanja Pegawai), Bendahara Pengeluaran \& KPA (Kuasa Pengguna Anggaran) / PPK (Pejabat Pembuat Komitmen)

c. Copy dokumen pendukung perubahan data pegawai yang dilegalisasi Kepala/pejabat berwenang

d. ADK (Arsip Data Komputer) terkait dengan perubahan data pegawai

e. Daftar hadir kerja selama 1 (satu) bulan

f. Laporan Kinerja Bulanan

g. Surat Setoran Pajak Penghasilan (PPh 21).

2. Belanja Barang dan Jasa. Checklist Pengeluaran yang harus diperiksa pada umumnya adalah:

a. Surat Permintaan Pembayaran lembar A, dimana tertulis total nominal yang harus dicairkan.

b. Surat Perintah Bayar (SPB) yang disetujui/ditandatangani PPK/KPA

c. Lampiran SPB (kuitansi/bukti pembelian lainnya yang telah disahkan PPK) 
d. Bukti setor pajak (bilamana terdapat kewajiban pajak).

3. Belanja Modal. Checklist Pengeluaran yang harus diperiksa pada umumnya adalah:

a. Surat Permintaan Pembayaran lembar A, dimana tertulis total nominal yang harus dicairkan.

b. Standar Dokumen Pengadaan (SDP), Dokumen Kualifikasi, TDP (Tanda Daftar Perusahaan), SPT ( Surat Pemberitahuan Tahunan) \& Laporan Pajak.

c. B.A. Klarifikasi \& Negosiasi Harga, B.A. Hasil Evaluasi Penawaran \& B.A. Hasil Pengadaan Langsung.

d. Bukti perjanjian/kontrak (SPK / Kontrak).

e. B.A. Serah Terima Barang/Pekerjaan.

f. Kuitansi bermeterai yang ditandatangani penyedia \& PPK.

g. Faktur pajak yang ditandatangani penyedia \& Surat Setoran Pajak (SSP) yg ditandatangani penyedia/Bendahara Pengeluaran.

h. Jaminan dari bank/lembaga keuangan lainnya bilamana dipersyaratkan.

4. Belanja Bantuan Sosial. Checklist Pengeluaran yang harus diperiksa pada umumnya adalah:

a. Surat Permintaan Pembayaran lembar A, dimana tertulis total nominal yang harus dicairkan

b. SK yg terdapat pernyataan bahwa "biaya yg timbul akibat penerbitan SK dibebankan pada DIPA (Daftar Isian Pelaksanaan Anggaran)"

c. Proposal permintaan bantuan dan fotokopi rekening

d. Kuitansi bermaterai

e. Daftar Nominatif Penerima

f. Petunjuk Teknis

g. Perjanjian Kerjasama

Untuk melakukan pengujian dokumen SPP (Surat Permintaan Pembayaran), verifikator harus mengacu pada PerMen Agama Nomor 2 Tahun 2007 tentang Mekanisme pelaksanaan pembayaran atas beban anggaran pendapatan dan belanja negara di lingkungan Departemen Agama. Mekanisme sesuai peraturan tersebut terdiri dari:

1. Wematigheid: Meneliti apakah suatu tagihan sudah berdasarkan perundang-undangan dan tersedia dana dalam DIPA.

2. Rechmatigheid: Meneliti apakah suatu transaksi dan perikatan sudah prosedurnya, lengkap persyaratannya, dan sah secara hukum;

3. Doelmatigheid: meneliti apakah suatu tagihan atau transaksi telah sesuai dengan kenyataan yang sebenarnya;

4. Formal: Meneliti apakah tidak ada kesalahan dalam penulisan dan penggunaan kode-kode baik dalam formullir SPP maupun SPM;

5. Kebenaran formal: adalah jika suatu tagihan pekerjaan /transaksi telah benar dilaksanakan sesuai dengan prosedur dan ketentuan yang berlaku, serta memenuhi persyaratan dan sah menurut hukum;

6. Kebenaran material: adalah jika suatu kegiatan/pekerjaan telah benar dilaksanakan sesuai dengan kenyataan. 
Flowchart

Mekanisme Pelaksanaan Aktivitas Pencairan Dana

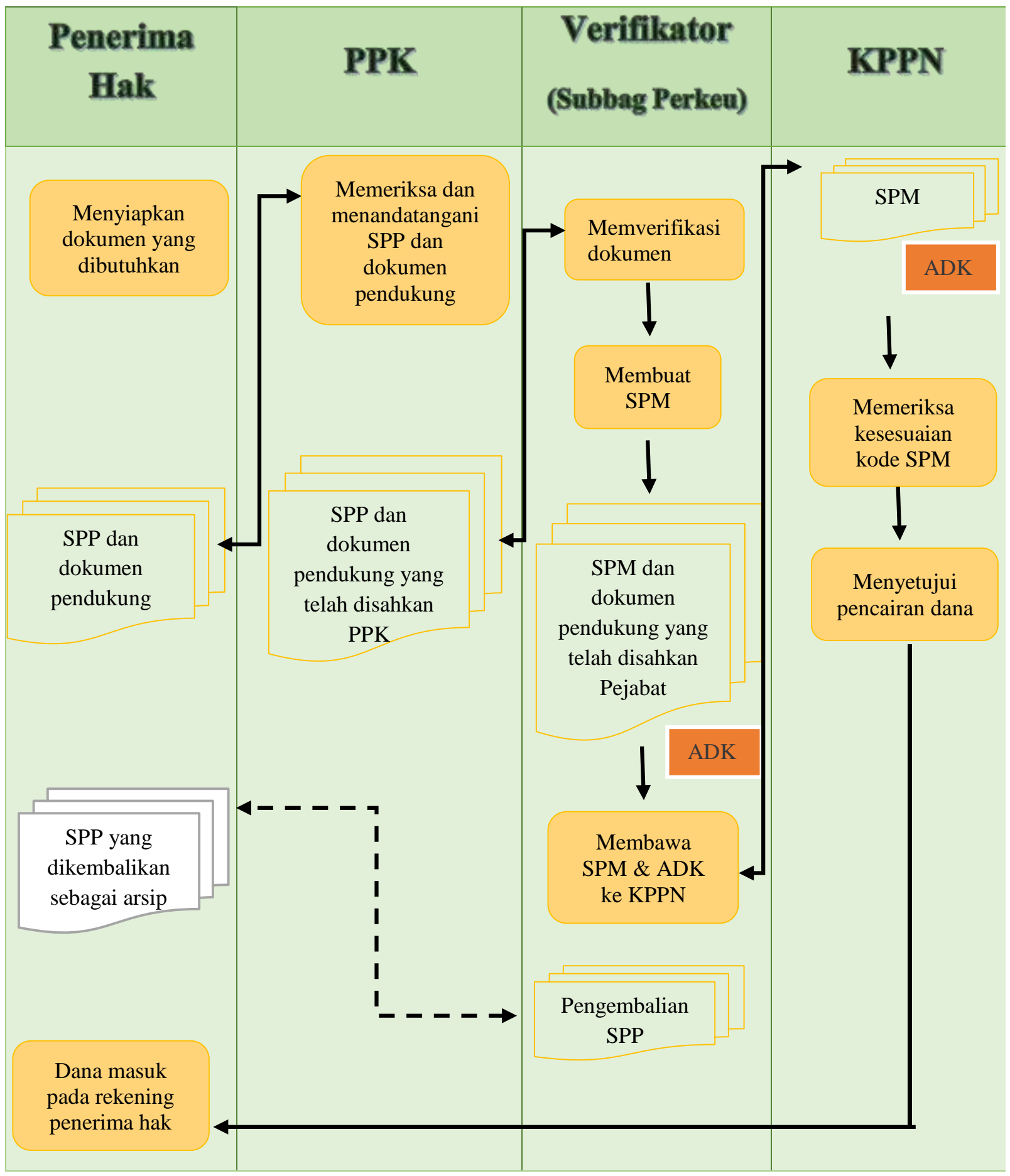

Peranan Sistem Informasi Akuntansi dalam Aktivitas Penncairan Dana pada Kanwil Kemenag Provinsi Sulut. Dengan adanya sistem informasi akuntansi, pegawai kantor Wilayah Kementerian Agama Provinsi Sulawesi Utara dapat mengetahui prosedurprosedur yang harus dilakukannya dalam mencapai suatu tujuan sehingga tidak terjadi kesalahpahaman yang berakibat serius bagi instansi yang terkait. Sistem informasi akuntansi juga sangat berperan penting bagi Kantor Wilayah Kementerian Agama Provinsi Sulut, 
khususnya pada sub bagian Perencanaan dan Keuangan sebagai pihak yang melakukan pemrosesan data keuangan. Namun dalam kantor ini, hasil informasi akuntansi yang paling sering digunakan adalah Informasi akuntansi manajemen untuk pengambilan keputusan. Dengan adanya sistem informasi akuntansi pada Kantor Wilayah Kementerian Agama Provinsi Sulut, akan menambah tingkat efisiensi kerja pada sub bagian keuangan sehingga kerja yang dilakukan menjadi lebih tepat dan tersrtuktur. Hal ini membuat pekerjaan menjadi lebih mudah sehingga pegawai dapat menyelesaikan pekerjaan lainnya tanpa memakan waktu yang lama.

\section{KESIMPULAN DAN SARAN}

\subsection{Kesimpulan}

Sistem Informasi Akuntansi mempunyai peranan yang sangat penting dalam studi kasus yang dilakukan pada objek yang terkait. Sehingga dalam hal ini teradapat 2 alasan yang menjadi dasar mengapa sistem informasi akuntansi ini sangat penting untuk menunjang aktivitas perusahaan. Yang pertama, dengan adanya Sistem Informasi Akuntansi yang baik, maka suatu perusahaan dapat melakukan aktivitas perusahaan dengan selalu mempertimbangkan tingkat efektivitas dan efisiensi daripada sistem yang dimaksud sehingga kedepannya hasil yang kemudian dicapai akan sesuai dengat yang diharapkan atau sesuai dengan tujuan perusahaan. Kemudian alasan yang kedua yaitu dikarenakan ketika sistem ini bersama-sama dengan sistem informasi lainnya menyediakan informasi yang berkualitas maka dari itu bagi pihak manajemen dalam suatu perusahaan dapat menjadikan ini sebagai salah satu bahan pertimbangan dalam pengambilan keputusan nantinya.

\subsection{Saran}

Sistem Informasi Akuntansi yang berlaku pada Kantor Wilayah Kementerian Agama sudah sangat bagus. Hal ini dapat dilihat dari prosedur pencairan dana yang dilakukan oleh subbag Perencanaan dan Keuangan. Saran yang bisa kami berikan adalah agar bisa menambah efektifitas sistem informasi akuntansi dalam semua kegiatan perusahaan khususnya yang berhubungan dengan akuntansi. Karena dengan meningkatnya sistem pada suatu perusahaan, maka meningkat pula kualitas informasi yang dibutuhkan oleh perusahaan tersebut, juga ketika semua itu terjadi maka tujuan dari instansi akan mudah tercapai.

\section{DAFTAR PUSTAKA}

Baridwan, Z., 1991, Sistem Akuntansi, Edisi Ke-5, Cetakan I, Yogyakarta.

Bodnar, H.G. dan Hopwood, W.S. 2010. Sistem Informasi Akuntansi. Buku I. Edisi Ke-6. Penerjemah Amir Abadi Jusuf dan Rudi M.Tambunan. Jakarta : Salemba Empat.

Daud, Rachmawati. 2014. "Pengembangan Sistem Informasi Akuntansi : Studi kasus pada PT.TRUST TECHNOLOGY”. Jurnal Manajemen dan Bisnis Sriwijaya Vol.12 No.1

Holmes, Scott and Des Nicholls. 1988, "An Analysis of The Use of Accounting Information by Australian Small Business," Journal of Small Business Management 26 (2):57.

Jogiyanto, H.M, Sistem Informasi Akuntansi Berbasis Komputer, Edisi II, Yogyakarta : BPFE.

KEMETERIAN AGAMA, Tugas dan Fungsi (online) https://suslut.kemenag.go.id. Tanggal akses 6 Desember 2018

M, Munifa. 2017. "Analasis Sistem dan Prosedur Penganggaran dalam Peningkatan Efektivitas Anggaran : Studi kasus kota Palu. Jurnal Katalogis, Vol.5 No.7.

Peraturan Menteri Agama RI Nomor 2 tahun 2007, tentang Mekanisme Pelaksanaan Pembayaran Atas Beban Anggaran Pendapatan dan Belanja Negara di Lingkungan Departemen Agama. 
Peraturan Menteri Agama RI Nomor 45 tahun 2014, tentang Pejabat Perbendaharaan Negara Pada Kementerian Agama.

Peraturan Menteri Agama RI Nomor 47 tahun 2017, tentang Monitoring Pelaksanaan Anggaran Secara Elektronik ada Kementerian Agama.

Peraturan Direktur Jenderal Perbendaharaan Nomor 13 tahun 2011, tentang Tata Cara Penyaluran Dana Surat Perintah Pencairan Dana (SP2D) dan Surat Perintah Transfer (SPT) melalui Bank Operasional.

Roomney, Marshal B. 2009. Accounting information system. Indonesia. Salemba Empat 